\title{
SISTEM PENGELOLAAN BUMDES \\ DALAM PEMBANGUNAN TAMBAK MILIK DESA LHOK EUNCIEN KECAMATAN BAKTIYA BARAT KABUPATEN ACEH UTARA
}

\author{
Lisa Iryani ${ }^{1)}$, Riska Mauliza \\ ${ }^{1}$ Program Studi Administrasi Bisnis Universitas Malikussaleh, lisairyani83@gmail.com
}

\section{ABSTRACT}

The Lhok Euncien Village Government established BUMDes as the driving force for the economy in the village, but its management has not been efficient. This is because the pond land which is a BUMDes business asset is handed over to a third party due to limited capital, so that BUMDes managers cannot work effectively and efficiently as they should. This research is focused on planning, organizing, mobilizing, and monitoring, as well as the obstacles faced in the BUMDes Lhok Euncien Village program. In addition, it also examines the limitations of capital and Human Resources (HR) and public awareness of the BUMDes program. This research uses descriptive research with qualitative methods. The results showed that at the planning stage, the pond had been purchased as an asset of BUMDes, but the limited capital to manage it was left to a third party. At the organizing stage, it was carried out according to the procedure, but it did not work and went according to plan. The mobilization stage is still constrained by a lack of concern from the village government, BUMDes managers, and the community about the problems faced. While at the supervision stage, BUMDes supervisors only supervise annual reports. Meanwhile, the obstacles faced are related to limited capital and the lack of human resources and public concern for the development of BUMDes businesses.

Keywords: Management System, BUMDes, Village Owned Ponds

\begin{abstract}
ABSTRAK
Pemerintah Desa Lhok Euncien membentuk BUMDes sebagai motor penggerak ekonomi desa, namun dalam pengelolaannya belum efisien. Hal ini disebabkan karena lahan tambak yang menjadi aset usaha BUMDes diserahkan pada pihak ketiga karena keterbatasan modal yang dimiliki, sehingga pengelola BUMDes tidak dapat bekerja secara efektif dan efisien sebagaimana mestinya. Penelitian ini difokuskan pada perencanaan, pengorganisasian, penggerakan, dan pengawasan, serta hambatan yang dihadapi dalam program BUMDes Gampong Lhok Euncien. Selain itu juga dikaji keterbatasan modal serta sumber daya manusia (SDM) dan kepedulian masyarakat terhadap program BUMDes. Penelitian ini menggunakan penelitian deskriptif dengan metode kualitatif. Hasil penelitian menunjukkan bahwa pada tahap perencanaan sudah membeli lahan tambak sebagai aset BUMDes, namun keterbatasan modal untuk mengelola sehingga diserahkan pada pihak ketiga. Pada tahap pengorganisasian sudah dilakukan sesuai prosedur, namun tidak berfungsi dan berjalan sesuai rencana. Tahap penggerakan masih terkendala kurangnya kepedulian dari pemerintah desa, pengelola BUMDes, serta masyarakat terhadap permasalahan yang dihadapi. Sementara pada tahap pengawasan, pengawas BUMDes hanya mengawasi laporan tahunan saja. Sedangkan hambatan yang dihadapi terkait dengan keterbatasan modal serta minimnya SDM dan kepedulian masyarakat terhadap perkembangan usaha BUMDes.
\end{abstract}

Kata Kunci: Sistem Pengelolaan, BUMDes, Tambak Milik Desa 


\section{PENDAHULUAN}

Gampong Lhok Euncien Kecamatan Baktiya Barat merupakan sebuah desa dengan jumlah penduduk 486 jiwa, dengan mayoritas penduduknya adalah petani tambak. Gampong Lhok Euncien merupakan desa yang terletak di daerah pesisir yang dikelilingi oleh sungai dan tambak. Dengan potensi tersebut masyarakat dan pemerintah desa memanfaatkan lahan tambak sebagai salah satu roda penggerak perekonomian desa. Selanjutnya didirikan Badan Usaha Milik Desa (BUMDes) sebagai pendukung usaha masyarakat yang bergerak dalam bidang perikanan, dimana memanfaatkan dana desa sebagai modal awal untuk pembelian lahan tambak sebagai salah satu unit bidang usaha BUMDes. Keberadaan lembaga ini memberi peluang kepada desa agar dapat berkembang dan mandiri, serta diharapkan meningkatkan pertumbuhan ekonomi dan kesejahteraan masyarakat setempat. Dalam memanfatkan potensi lahan tambak atau sumber daya alam yang ada, Gampong Lhok Euncien memerlukan sumber daya manusia (SDM) yang mampu mengelola, mengembangkan, dan menjaga BUMDes sebagai salah satu aset desa dan memberi inovasi-inovasi baru demi meningkatkan perekonomian dan pembangunan desa.

Gampong Lhok Euncien merupakan salah satu desa yang telah membentuk BUMDes di Kecamatan Baktiya Barat. Pembentukan dan pengelolaan BUMDes yang ada Gampong Lhok Euncien kemudian diberi nama BUMDes Keunebah Indatu. Melihat adanya potensi yang dimiliki Gampong Lhok Euncien diperlukan adanya suatu program yang akan mengelola BUMDes guna menghasilkan pendapatan bagi desa tersebut. Berdasarkan hasil wawancara awal yang peneliti lakukan dengan Bapak Rusli selaku Kepala Desa menyatakan bahwa terdapat banyak potensi yang dimiliki Gampong Lhok Euncien yang selama ini belum dimanfaatkan dengan baik bagi kesejahteraan masyarakat. Hal ini menjadi alasan BUMDes didirikan (hasil wawancara awal, 2018).

Meskipun demikian pelaksanaan BUMDes di Gampong Lhok Euncien menghadapi suatu hambatan dalam sistem pengelolaannya, dimana tambak milik BUMDes diserahkan pengelolaannya pada pihak ketiga, yang seharusnya dikelola sendiri. Hal ini dinilai lebih menguntungkan bagi pihak ketiga ketimbang BUMDes tersebut.

Ketidakefektifan pengelolaan BUMDes juga terjadi di daerah lain. Penelitian terdahulu dilakukan oleh Manikam (2010). Hasil penelitian menunjukkan bahwa implementasi program Badan Usaha Milik Desa di Gunungkidul belum berjalan dengan baik. Kenyataan tersebut dapat dilihat dari tingkat partisipasi masyarakat desa masih rendah serta program-program Badan Usaha Milik Desa yang belum berjalan secara keseluruhan serta belum dapat mengakomodir kepentingan, potensi, serta kebutuhan petani sebagaimana tujuan utama pendirian BUMDes tersebut. Berbeda 
dengan hasil penelitian Manikam, penelitian lain yang dilakukan oleh Abu (2019) di Kabupaten Buton Utara justru menunjukkan bahwa pengurus dan anggota BUMDes telah berperan baik dalam melayani pemodalan perekonomian masyarakat.

\section{Strategi Pembangunan melalui Badan Usaha Milik Desa}

Budiman (1995) melihat pembangunan dari sudut pandang pesimistik karena setiap pembangunan tidak ramah pada orang-orang yang tersingkir. Tetapi suatu negara tidak mungkin berjalan tanpa pembangunan. Persoalannya sekarang adalah bagaimana merangkul kaum marginal tersebut agar dapat juga merasakan kue pembangunan.

Pembangunan hendaknya dilaksanakan secara terencana (Subandi, 2011), bergerak maju ke depan (Rostow dalam Damanhuri, 2010), dan diputuskan sesuai dengan kehendak suatu bangsa (Harun \& Ardianto, 2011). Untuk mencapai "kehidupan yang lebih baik" bagi sebuah masyarakat, Todaro (2000) menyarankan tiga hal, yakni distribusi kebutuhan, penyediaan lapangan kerja, dan pembebasan dari ketergantungan.

Selama masa Orde Baru, desa tampaknya kurang diperhatikan dalam agenda pembangunan. Landasan umum desa yang terdiri atas keanekaragaman, partisipasi, otonomi, demokratisasi, dan pemberdayaan masyarakat (Widjaja, 2005) diabaikan oleh Pemerintah Pusat. Proses pembangunan desa seharusnya melalui mekanisme keinginan masyarakat yang dipadukan dengan gagasan pemerintah. Perpaduan tersebut menentukan keberhasilan pembangunan (Ahmadi \& Uhbiyati, 2001) karena dilakukan secara seimbang dalam sebuah kolaborasi (Suparno \& Suhaenah, 2001). Kansil (1983) menyatakan realisasi pembangunan desa hendaknya memperhatikan beberapa aspek yakni komprehensif multisektoral, perpaduan sasaran sektoral/regional dengan kebutuhan esensial, pemerataan, integrasi desa-kota, serta senantiasa menggerakkan partisipasi, swadaya dan gotong royong. Dengan demikian, pembangunan pedesaan menerapkan strategi terpadu atau menyeluruh (Adisasmita, 2006).

Salah satu bentuk program pembangunan yaitu pendirian dan pengelolaan Badan Usaha Milik Desa (BUMDes) dengan mengedepankan partisipasi masyarakat secara keseluruhan yang didirikan berdasarkan peraturan desa tentang pendirian Badan Usaha Milik Desa (BUMDes). Badan Usaha Milik Desa (BUMDes) didirikan atas pertimbangan penyaluran inisiatif masyarakat desa, pengembangan potensi desa, pengelolaan, pemanfaatan potensi desa, pembiayaan, dan kekayaan pemerintah desa yang diserahkan untuk dikelola oleh Badan Usaha Milik Desa (BUMDes). 
Pengelolaan pedesaan adalah pemanfaatan seluruh faktor sumberdaya pedesaan (Admosudirjo, 2005). Pengelolaan yang baik merupakan fondasi (Arif, 2007) dalam pembangunan. Terdapat empat fungsi pengelolaan, yakni perencanaan, pengorganisasian, penggerakan, dan pengawasan (Terry, 2005).

\section{METODE PENELITIAN}

Penelitian ini menggunakan pendekatan kualitatif dengan metode deskriptif (Emzir, 2011). Pendekatan kualitatif penulis anggap sangat relevan untuk mengkaji dan mendeskripsikan tentang bagaimana manajemen pengelolaan Badan Usaha Milik Desa dalam Pembangunan tambak milik desa. Penelitian deskriptif adalah penelitian yang berusaha untuk menuturkan pemecahan masalah yang ada dengan disajikan, dianalisis, dan diinterpretasi (Narbuko \& Achmadi, 2007). Metode kualitatif deskriptif digunakan untuk mengetahui secara mendalam mengenai sesuatu yang sedang terjadi dengan memahami fenomena yang dialami yaitu melihat perilaku, persepsi, dan tindakan. Informan dipilih dari masyarakat maupun lembaga terkait sesuai dengan data yang yang dibutuhkan oleh penulis setelah melihat kondisi di lapangan dengan kombinasi teknik purposif dan snowball (Sugiyono, 2010). Data primer diperoleh melalui wawancara dan pengamatan, sedangkan data sekunder diperoleh dengan menelusuri dokumen, peraturan perundang-undangan yang relevan, buku, jurnal, makalah, informasi online, pengumuman, surat-surat, dan spanduk (Iskandar, 2009). Instrumen pengumpulan data terdiri dari observasi, wawancara, dan dokumentasi (Herdiansyah, 2010). Dalam menganalisis data peneliti melakukan beberapa teknik analisis data, (Sugiyono, 2010) antara lain pengumpulan data, reduksi data, penyajian data, dan penarikan kesimpulan.

\section{HASIL DAN PEMBAHASAN}

\section{Sistem Pengelolaan Badan Usaha Milik Desa (BUMDes) dalam Pembangunan Tambak Gampong Lhok Euncin}

Gampong Lhok Euncien memiliki luas wilayah 124 hektar, yang terdiri dari dua dusun yaitu Dusun Puloe Blang dan Dusun Pang Woud. Desa dengan mayoritas lahan pertambakan ini, mempunyai luas lahan tambak sekitar 43 hektar. Secara geografis jarak tempuh Gampong Lhok Euncien ke ibukota kecamatan adalah $10 \mathrm{~km}$ dengan jarak tempuh waktu sekitar 20 menit. Sedangkan jarak tempuh ke ibukota kabupaten adalah $20 \mathrm{~km}$ dengan jarak tempuh sekitar 40 menit. Dengan mayoritas masyarakat yang berprofesi sebagai petani tambak, pertambakan merupakan aset utama untuk dimobilisasi demi kesejahteraan masyarakat. Pertambakan telah menunjang 
ekonomi masyarakat setempat, karena masyarakat menjadikannya modal produksi untuk budidaya ikan dimana dari hasil tersebut masyarakat memperoleh pendapatan untuk memenuhi kebutuhan sehari-hari.

Gampong Lhok Euncien juga terdapat sungai yang berhubungan dengan aset tambak. Masyarakat yang berprofesi sebagai petani tambak mengandalkan air sungai tersebut untuk mengairi tambak mereka. Berbagai jenis ikan dibudidayakan, namun masyarakat Gampong Lhok Euncien lebih sering membudidayakan bibit ikan bandeng. Alasannya karena modal yang kecil, mudah perawatan dan panen, jarang terkena hama atau wadah penyakit, dan hasil panennya pun lumayan menjanjikan.

Pertambakan telah menjadi penopang hidup masyarakat. Maka diperlukan langkah-langkah untuk memobilisasi potensi di bidang perikanan tersebut. Salah satu upaya yang dilakukan oleh pemerintah Gampong Lhok Euncien berdasarkan hasil musyawarah desa, timbul inisiatif dimana untuk menggali potensi yang dimiliki desa tersebut adalah dengan mendirikan Badan Usaha Milik Desa atau BUMDes yang berhubungan dengan pertambakan sebagai potensi dasar desa tersebut. Pemerintah Gampong Lhok Euncien membentuk BUMDes sebagai wadah dalam rangka optimalisasi pemberdayaan masyarakat sehingga masyarakat bisa berkembang sesuai dengan kreativitas dan kemampuan yang mereka miliki.

Salah satu misi pemerintah adalah membangun daerah pedesaan yang dapat dicapai melalui pemberdayaan masyarakat untuk meningkatkan produktivitas dan keanekaragaman usaha pedesaan. Pemerintah Gampong Lhok Euncien Kecamatan Baktiya Barat kemudian membentuk Badan Usaha Milik Desa (BUMDes) dengan nama "Keuneubah Indatu” pada tahun 2017. Pendirian BUMDes Keuneubah Indatu melalui dua tahapan penting, yaitu musyawarah desa dan menyusun rancangan Qanun BUMDes. Dalam dua tahapan penting ini dilakukan sosialisasi kepada masyarakat desa tentang peluang pendirian BUMDes dan menyepakati pendirian BUMDes sesuai dengan kondisi ekonomi, potensi, jenis usaha, dan sosial budaya masyarakat. Kemudian disusun draf Anggaran Dasar dan Anggaran Rumah Tangga BUMDes dan menentukan kriteria pengurus organisasi pengelola BUMDes.

Permodalan atau pembiayaan BUMDes Keuneubah Indatu diperoleh dari sumber dana desa yang berasal dari Pemerintah Pusat, Pemerintah Provinsi, dan Pemerintah Kabupaten. Pemodalan diperuntukkan khusus untuk bidang perikanan. Kepengurusan BUMDes Keuneubah Indatu ditetapkan berdasarkan hasil dari musyawarah desa yang terdiri dari unsur pemerintah desa (Kepala Desa), lembaga adat (LPMD), dan unsur masyarakat, dengan masa berlaku kepengurusan selama tiga tahun. Struktur kepengurusan BUMDes Keuneubah Indatu sebagai berikut :

211 | Jurnal Ilmu Sosial dan Ilmu Politik Malikussaleh (JSPM) Volume 1 Nomor 2 Tahun 2020 
Bagan 1. Struktur Organisasi Kepengurusan BUMDes Keuneubah Indatu

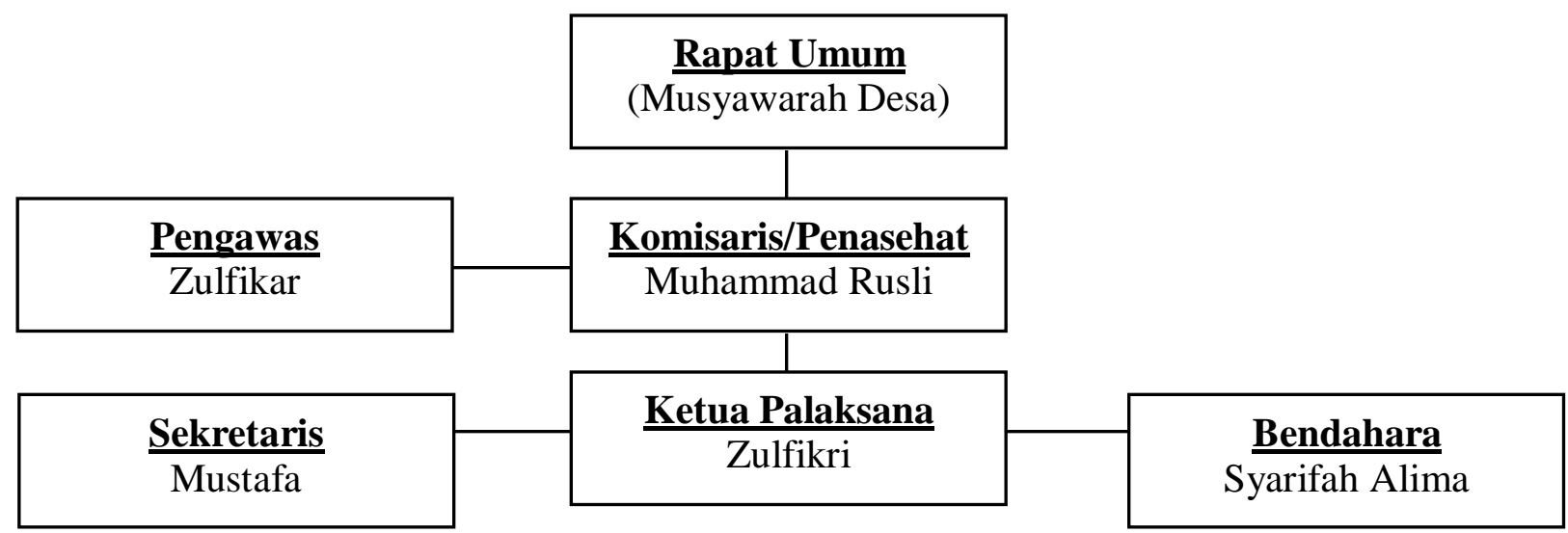

Berdasarkan uraian di atas dapat diketahui bahwa BUMDes Keuneubah Indatu Gampong Lhok Euncien merupakan usaha pemerintah desa dari aset yang dipisahkan. Maka peranan BUMDes seperti yang diharapkan semua pihak merupakan strategi dalam mendukung cadangan devisa desa guna mendukung peningkatan kesejahteraan masyarakat, membuka lapangan kerja, serta meningkatkan pendapatan asli desa (PAD) sehingga menjadi desa mandiri dan berkembang.

\section{a. Perencanaan}

Berdasarkan wawancara dengan Geucik Gampong Lhok Euncien BUMDes dibentuk dalam rangka mendukung roda perekonomian desa, sebagaimana diutarakan:

"Dibentuknya BUMDes ini karena Lhok Euncien belum memiliki program yang bersifat pemberdayaan masyarakat. Selama ini bantuan dari pemerintah melalui Dana Desa lebih diutamakan dalam pembangunan insfrastruktur dibandingkan program pemberdayaan, dan diharapkan dengan adanya program ini dapat meningkatkan pendapatan bagi desa dan meningkatkan perekonomian bagi masyarakat." (Muhammad Rusli, Lhok Encien, 26/04/2019)

Pembelian aset BUMDes berupa lahan tambak dilakukan secara bertahap. Geucik Lhok Euncien menambahkan:

"Pada tahap awal untuk tahun ini kami hanya dapat membeli lahan tambak sebagai aset desa (BUMDes) karena minimnya modal... untuk sementara lahan tambak kami sewakan untuk pembayaran operasional pengurus serta untuk pemeliharaan lahan tambak, sedangkan untuk pengelolaan kami berinisiatif akan mengelolanya sendiri lahan tambak tersebut pada tahun selanjutnya dengan memanfaatkan anggaran dana desa tahun 2018." (Muhammad Rusli, Lhok Encien, 26/04/2019) 
Berdasarkan wawancara dengan salah seorang penduduk Gampong Lhok Euncien, informan menyampaikan bahwa modal yang serba tanggung menjadi kendala yang membuat BUMDes lambat bergerak, seperti disampaikan:

"Menurut yang saya lihat perencanaan pendirian BUMDes Keuneubah Indatu sudah benar dengan membeli lahan tambak untuk dijadikan usaha atau aset desa demi perkembangan ekonomi desa serta membuka lapangan kerja baru untuk masyarakat desa. Namun terdapat sedikit kendala setelah membeli lahan tambak, desa tidak memiliki dana lagi untuk dijadikan modal usaha untuk mengelola lahan tambak tersebut sehingga desa menyewakan tambak tersebut dan tidak dikelola sendiri oleh pengurus atau pengelola BUMDes." (Sofyan, Lhok Encien, 28/04/2019)

Keterangan di atas dikonfirmasi oleh Sekretaris BUMDes Gampong Lhok Euncien. Menurut informan:

"Perencanaan BUMDes keunebah Indatu tidak berjalan sesuai dengan yang diharapkan dimana keterbatasan modal membuat kami selaku pengelola tidak bisa mengelola dan menjalankan sendiri usaha BUMDes sehingga lahan tambak desa atas persetujuan bersama berdasarkan hasil musyawarah mengambil inisiatif untuk disewakan dengan harga Rp. 5.500.000,- selama satu tahun, dan sampai sekarang menjelang tahun kedua desa tidak menganggarkan dana untuk pengelolaan dan pembiayaan BUMDes." (Mustafa, Lhok Encien, 26/04/2019)

\section{b. Pengorganisasian}

Pengorganisasian bertujuan untuk membentuk unit-unit kerja yang teroganisir dalam mencapai tujuan usaha. Dengan adanya pengorganisasian maka akan memperjelas deskripsi kerja serta target pencapaian kerja. Tanpa adanya pengorganisasian suatu program yang dibentuk sulit untuk berjalan dan dipertanggungjawabkan, karena jika ada masalah tidak tahu siapa yang mengerjakan dan bertanggung jawab sehingga program yang dikelola menjadi terbengkalai tanpa ada pengurus yang jelas dalam mengelolanya. Berdasarkan wawancara dengan Geucik Gampong Lhok Euncien, kepengurusan BUMDes dibentuk dengan asas musyawarah mufakat sebagaimana petikan wawancara berikut:

"Pengorganisasian BUMDes Keuneubah Indatu dibentuk di luar organisasi pemerintahan desa... namun dalam pembentukan pengorganisasian BUMDes Keuneubah Indatu kami melakukannya secara musyawarah desa, dimana membentuk tim pengelola BUMDes yang terdiri dari penasehat, pengawas, ketua pengelola, sekretaris, dan bendahara yang dipilih secara musyawarah desa atas kesepakatan bersama”. (Muhammad Rusli, Lhok Encien, 26/04/2019)

Namun dari keterangan yang disampaikan oleh salah seorang penduduk Gampong Lhok Euncien dipahami bahwa proses penjaringan pengurus belum menghasilkan kinerja yang optimal sebagaimana disampaikan:

213 | Jurnal Ilmu Sosial dan Ilmu Politik Malikussaleh (JSPM) Volume 1 Nomor 2 Tahun 2020 
"Dalam pengorganisasian BUMDes Keuneubah Indatu para pengurus BUMDes ditetapkan berdasarkan kemampuan dan keahlian dari masing-masing individu, akan tetapi mereka kurang memahami tentang penempatan tugas dan fungsi sehingga pekerjaan tidak berjalan secara efisien dan efektif." (Ridwan, Lhok Encien, 28/04/2019)

Senada dengan pernyataan di atas, salah seorang penduduk yang lain menyatakan ketidakpuasannya sebagaimana diungkapkan:

"Dalam pengorganisasian BUMDes Keuneubah Indatu para pengurus BUMDes diberi wewenang atau hak untuk melakukan suatu pekerjaan agar tercapainya suatu tujuan yang ingin dicapai oleh organisasi... namun wewenang tersebut tidak dimanfaatkan dan dijalankan (BUMDes bejalan dengan apa adanya tanpa suatu tindakan yang diambil oleh pengelola atas berbagai permasalahan yang dialami oleh BUMDes).” (Fadli, Lhok Encien, 28/04/2019)

Para informan kemudian menambahkan:

"Dalam pengorganisasian BUMDes Keuneubah Indatu, kurang tanggung jawab pengurus dan pemerintah desa dimana tanggung jawab yang diberikan tidak dilaksanakan dengan sebaik mungkin... kesadaran dan kepedulian pengurus masih kurang sehingga permasalahan dalam BUMDes tidak pernah diselelesaikan". (Fadli, Lhok Encien, 28/04/2019)

"Menurut saya BUMDes keuneubah Indatu dalam proses penggerakan terjadinya miss komunikasi antara atasan dengan bawahan, sehingga mengakibatkan kelalaian akan tugas dan fungsi masing-masing." (Faisal, Lhok Encien, 28/04/2019)

\section{c. Penggerakan}

Fungsi penggerakan adalah untuk memberikan bimbingan dan saran agar pengurus

BUMDes mampu bekerja secara optimal serta memberikan perintah dalam pelaksanaan tugas agar dapat mencapai tujuan yang ingin dicapai. Terkait hal ini, Bendahara BUMDes Keuneubah Indatu mengatakan:

"Menurut saya pada tahun pertama penggerakan BUMDes berjalan dengan baik dimana terdapat respon positif dan dukungan dari pemerintah desa dan masyarakat setempat serta terdapat beberapa saran dan bimbingan dari pemerintah desa dan masyarakat untuk pengembangan BUMDes. Namun pada tahun selanjutnya BUMDes menjadi terbengkalai dimana kurangnya perhatian pemerintah desa dan masyarakat setempat sehingga kami selaku pengelola mengalami kesulitan untuk mengembangkan BUMDes." (Syarifah Alima, Lhok Encien, 26/04/2019)

Permasalahan ini menurut salah seorang anggota masyarakat karena BUMDes tidak benarbenar digerakkan secara bersama-sama. Informan mengutarakan:

"BUMDes Keuneubah Indatu tidak memiliki tim pengerak yang mampu menyelesaikan permasalahan yang terjadi dalam BUMDes baik dari segi modal usaha maupun sistem pengelola... Menurut saya BUMDes Keuneubah Indatu dalam penggerakan masih kurang 
perhatian atau kepedulian pemerintah desa, pengelola BUMDes, serta masyarakat setempat, sehingga menjadi sedikit terhambat perkembangan BUMDes.” (Ridwan, Lhok Encien, 28/04/2019)

Sementara itu, kendala BUMDes menurut anggota masyarakat yang lain berhubungan erat dengan kapasitas dan kapabilitas pengelola yang tidak mendapatkan pelatihan yang mumpuni sehingga menghambat jalannya organisasi. Masalah lain terkait dengan minimnya gagasan cemerlang yang datang dari stakeholder dalam mendukung kemajuan BUMDes. Informan menyuarakan:

"Menurut saya BUMDes keuneubah Indatu dalam proses penggerakan kurangnya bimbingan kepada pengelola BUMDes sehingga mereka kurang memahami... maka menurut saya diperlukan bimbingan agar apa yang menjadi kekurangan atau kendala dalam BUMDes dapat diminimalisir." (Said Abu Bakar, Lhok Encien, 26/04/2019)

"BUMDes keuneubah Indatu dalam proses penggerakan kekurangan ide dan saran-saran yang dapat dipertimbangkan, baik itu saran dari pemerintah desa maupun masyarakat desa bersifat membangun.” (Faisal, Lhok Encien, 28/04/2019)

\section{d. Pengawasan}

Pengawasan adalah proses dalam menetapkan ukuran kinerja dan pengambilan tindakan yang dapat mendukung pencapaian hasil yang diharapkan sesuai dengan kinerja yang telah ditetapkan tersebut. Pengawasan memegang peranan penting dalam pengelolaan BUMDes, karena kelembagaan ini diharapkan dapat berjalan secara berkelanjutan.

Tujuan dari pengawasan adalah menjamin berjalannya pekerjaan sesuai dengan perencanaan, kebijakan, dan prosedur yang ditetapkan, serta menyampaikan laporan hasil pengawasan disertai saran dan pendapat kepada pemerintah desa. Tanpa adanya pengawasan yang baik, tentunya pencapaian tujuan kurang memuaskan, baik bagi program BUMDes maupun bagi para anggotanya. Berdasarkan wawancara Sekretaris BUMDes Gampong Lhok Euncien, informan mengatakan:

"Pada tahap pengawasan BUMDes Keuneubah Indatu masih kurangnya keterlibatan dari anggota pengawas pusat dari pemerintah desa... bahkan masyarakat setempat dalam mengawasi BUMDes Keuneubah Indatu tidak optimal sehingga BUMDes tidak berjalan secara efektif dan tidak sesuai rencana." (Mustafa, Lhok Encien, 26/04/2019)

Selanjutnya berdasarkan wawancara dengan pengawas BUMDes Gampong Lhok Euncien dipahami bahwa pengawasan tidak memungkinkan untuk dilakukan karena programnya saja belum benar-benar terlaksana di lapangan, seperti diungkapkan:

"BUMDes Keuneubah Indatu tidak berjalan sesuai dengan fungsinya sehingga dalam tahap pengawasan lapangan saya tidak tahu apa yang harus saya awasi dikarenakan tambak desa 
yang merupakan aset BUMDes telah disewakan... jadi saya hanya mengawasi pendapatan dan laporan tahunan dari pengelola BUMDes.” (Zulfikar, Lhok Encien, 28/04/2019)

Berdasarkan wawancara dengan Bendahara BUMdes Gampong Lhok Euncien mengatakan bahwa:

"Menurut saya pengawasan tidak hanya dilakukan oleh pengawas BUMDes, namun perlu juga pengawasan dari masyarakat setempat, karena tahap pengawasan tidak hanya berfokus pada pengawasan lapangan namun juga pengawasan pada tahapan pengembangan dan permasalahan yang dialami oleh BUMDes.” (Syarifah Alima, Lhok Encien, 26/04/2019)

\section{Hambatan atau Kendala dalam Pengelolaan Badan Usaha Milik Desa (BUMDes) di Desa}

\section{Lhok Euncien}

\section{a. Keterbatasan Modal}

Keberhasilan program pemberdayaan masyarakat salah satunya ditentukan oleh modal usaha yang memadai disertai dengan dukungan dari pemerintah desa. Dengan modal usaha tersebut desa dapat mengembangkan usaha BUMDes secara lebih optimal. Dengan demikian akan tersedia lapangan kerja baru untuk masyarakat desa yang tidak memiliki pekerjaan tetap. Berdasarkan wawancara dengan Bendahara BUMDes Keuneubah Indatu Gampong Lhok Euncien, informan menyampaikan:

"Adapun hambatan dalam pengelolaan BUMDes ini adalah dikarenakan minimnya penyertaan modal bahkan tidak dianggarkan sama sekali untuk tahun yang direncanakan... padahal dalam perencanaan awal anggaran tahun 2018 akan dialokasikan untuk pengembangan BUMDes, tetapi sampai sekarang ini BUMDes tidak mendapatkan dana atau anggaran untuk pengembangan usaha sehingga BUMDes menjadi terbengkalai." (Syarifah Alima, Lhok Encien, 26/04/2019)

Namun, sebagaimana diutarakan oleh anggota LPMD Gampong Lhok Euncien, program ini sejak awal memang sudah bermasalah dan tidak diperkirakan dengan baik. Buruknya perencanaan mengakibatkan modal yang ada pada saat ini tidak dioptimalkan dengan cara yang benar. Informan menyampaikan:

"Keterbatasan modal menjadi puncak awal permasalahan yang terjadi dalam pengelolaan BUMDes ini yaitu dengan kurangnya modal untuk mengelola dan mengembangkan BUMDes sehingga lahan tambak yang menjadi aset untuk dikelola oleh BUMDes malah disewakan pada pihak ketiga dikarenakan tidak adanya modal untuk mengelola." (Jurjani, Lhok Encien, 28/04/2019)

Sementara itu, anggota masyarakat Gampong Lhok Euncien yang lain merasa pemerintah terkesan terlalu menekankan pembangunan infrastruktur ketimbang pemberdayaan masyarakat. akibatnya, program BUMDes tidak didukung dengan sepenuh hati, seperti dinyatakan:

216 | Jurnal Ilmu Sosial dan Ilmu Politik Malikussaleh (JSPM) Volume 1 Nomor 2 Tahun 2020 
"Pemerintah desa dalam menyusun rencana anggaran desa lebih mementingkan pembangunan infrastruktur dibandingkan mengembangkan usaha BUMDes yang sudah didirikan sebelum ini, yang seharusnya program pemberdayaan inilah yang diutamakan jangan dibiarkan tidak terurus dan terbengkalai." (Sofyan, Lhok Encien, 28/04/2019)

Akar permasalahan yang sama disampaikan oleh Bendahara BUMDes Keuneubah Indatu Gampong Lhok Euncien, informan mengatakan bahwa:

"Seharusnya pemerintah desa lebih bijak dalam menyusun anggaran, misalkan anggaran yang ada dibagi menjadi dua bagian yaitu setengah untuk pembangunan insfrastruktur dan setengahnya lagi untuk pengembangan BUMDes... dengan begitu BUMDes dapat mengembangkan usahanya, usaha BUMDes ini untuk kepentingan desa juga bukan untuk sekelompok orang saja... jadi pemerintah desa harus memikirkan akar permasalahan yang selama ini terjadi." (Syarifah Alima, Lhok Encien, 26/04/2019)

Menurut Sekretaris BUMDes Keuneubah Indatu Gampong Lhok Euncien, kendala anggaran ini membuat pihak pengelola kesulitan bergerak dan tidak berdaya untuk menjalankan roda organisasi BUMDes. Hal itu sebagaimana diungkapkan:

"Dengan keterbatasan bahkan tidak ada modal untuk mengembangkan usaha BUMDes ini sehingga kami sebagai pengurus dan pengelola BUMDes tidak bisa bekerja dengan efektif dan maksimal walaupun ini merupakan tanggung jawab bagi semua pengurus BUMDes untuk mengembangkan usaha agar tercapainya tujuan." (Mustafa, Lhok Encien, 26/04/2019)

Namun kendala ini tidak demikian dalam pandangan masyarakat Gampong Lhok Euncien. Para pengurus tetap menjadi sasaran kambing hitam atas tidak efektifnya pengelolaan BUMDes di desa mereka sebagaimana disampaikan:

"Selama ini pengurus BUMDes kurang tegas dalam hal mengambil keputusan dalam hal menyikapi permasalahan yang selama ini terjadi, seharusnya para pengurus BUMDes bersikeras meminta bantuan modal atau meminta supaya anggaran dana desa dialokasikan untuk pengelolaan BUMDes, karena ini sudah menjadi tugas dan tanggung jawab pihak pengurus BUMDes.” (Ridwan, Lhok Encien, 28/04/2019)

"Dalam pengelolaan BUMDes ini seharusnya para pengelola BUMDes harus benar-benar mengerti dan mengetahui bagaimana cara mengelola program pemberdayaan yang sudah ada supaya menjadi berkembang bukan hanya menunggu perintah dari pemerintah desa melainkan mempunyai inisiatif dari antar anggota BUMDes untuk bagaimana caranya agar BUMDes berjalan sesuai dengan perencanaan, karena ini merupakan tanggung jawab yang harus dilaksanakan oleh seluruh pengurus BUMDes untuk memajukan program ini”. (Faisal, Lhok Encien, 28/04/2019)

b. Minimnya SDM dan Kepedulian Masyarakat Terhadap Pengelolaan BUMDes

Pengelolaan BUMDes harus didukung oleh sumber daya yang memadai, baik sumber daya manusia maupun sumber daya alam. Program BUMDes menjadi tidak efektif apabila terdapat 
keterbatasan sumber daya manusia dalam menjalankan BUMDes. Kurangnya koordinasi yang baik antara pengurus juga akan memperburuk program BUMDes yang dijalankan. Tanpa sumber daya yang mampu mengatur dan mengurus BUMDes, lembaga ini hanya akan menjadi perencanaan tanpa hasil. Sementara partisipasi masyarakat juga menjadi tolak ukur keberhasilan BUMDes dalam mengelola dan mengembangkan usaha.

Berdasarkan hasil wawancara dengan Sekretaris BUMDes Keuneubah Indatu Gampong Lhok Euncien, informan mengatakan bahwa:

"Untuk mengelola BUMDes seharusnya pemerintah desa dan masyarakat memilih orangorang yang benar-benar mengerti dan mengetahui alasan serta tujuan pembentukan BUMDes ini... Dikarenakan para pengelola BUMDes mendapatkan tanggung jawab bagaimana mengelola BUMDes ke depannya, jadi seharusnya pucuk dari pimpinan BUMDes harus mempunyai jiwa kewirausahaan yang tinggi." (Mustafa, Lhok Encien, 26/04/2019)

Sebaliknya pengawas program BUMDes justru melemparkan tuduhan kepada masyarakat yang terkesan tidak peduli dengan program BUMDes sebagaimana dijelaskan:

"Program BUMDes ini sebelumnya telah disosialisasikan, namun masalah yang terjadi adalah ketidakpedulian masyarakat kita terhadap program BUMDes tersebut. Masyarakat kita hari ini sudah apatis, banyak yang tidak peduli terhadap program yang dikeluarkan ataupun yang dibuat oleh pemerintah yang sebenarnya menguntungkan bagi keseluruhan masyarakat apabila dikelola dengan baik”. (Zulfikar, Lhok Encien, 28/04/2019)

Opini yang lebih moderat disampaikan oleh anggota LPMD Gampong Lhok Euncien. Menurut informan:

"Dalam pengelolaan BUMDes sebelumnya telah disosialisasikan bagaimana cara mengelola BUMDes, namun masalah yang terjadi adalah masih kurangnya kepedulian antara pengurus BUMDes, masyarakat serta pemerintah desa terhadap program BUMDes tersebut... ada Sumber Daya Manusia (SDM) yang mampu untuk mengelola tetapi tidak mau terlibat dikarenakan mempunyai pekerjaan sendiri.” (Jurjani, Lhok Encien, 28/04/2019)

\section{Pembahasan}

Tujuan yang ingin dicapai oleh Badan Usaha Milik Desa (BUMDes) Keuneubah Indatu Gampong Lhok Euncien adalah terciptanya masyarakat yang sejahtera serta meningkatkan perekonomian desa dan membuka lapangan kerja baru bagi masyarakat desa. Selain itu juga memudahkan dan membantu masyarakat Gampong Lhok Euncien dalam bidang perekonomian. Dengan kata lain usaha yang dibentuk dapat memberi keuntungan sosial kepada masyarakat dan desa memiliki pendapatan sendiri tanpa harus bergantung pada pemerintahan yang lebih tinggi.

218 Jurnal Ilmu Sosial dan Ilmu Politik Malikussaleh (JSPM) Volume 1 Nomor 2 Tahun 2020 
Dalam proses pencapaian tujuan program, BUMDes Keuneubah Indatu Gampong Lhok Euncien juga membentuk prosedur dalam menjalankan programnya. Prosedur tersebut dituangkan dalam Qanun BUMDes. Dasar program perencanaan BUMDes Keunebah Indatu Gampong Lhok Euncien yaitu membeli lahan tambak yang rencananya akan dikelola sendiri oleh BUMDes. Program ini tidak berjalan sesuai rencana karena keterbatasan modal sehingga pihak gampong harus menyewakan lahan tambak tersebut. Tindakan menyewakan lahan oleh pengurus BUMDes sehingga BUMDes tersebut tidak berjalan sesuai rencana awal dirasionalisasi dengan keterbatasan modal. Hal ini meninggalkan permasalahan baru bagi BUMDes dimana pemerintah gampong dan masyarakat dalam prosesnya tidak lagi peduli akan perkembangan BUMDes dan dibiarkan terbengkalai begitu saja. Jika tidak ditangani hal ini akan menjadi hambatan baru dalam perkembangan BUMDes ke depannya.

Berdasarkan hasil penelitian, para pengurus BUMDes Keuneubah Indatu sudah mengetahui tugasnya masing-masing, namun dalam tahap pelaksanaan tidak berjalan optimal. Kenyataannya BUMDes masih belum mengalami perkembangan dan kemajuan. Pengamatan penulis menemukan tidak ada upaya yang signifikan dalam mengatasi permasalahan yang dihadapi dalam pengelolaan BUMDes.

Hasil temuan di lapangan menunjukkan bahwa pada awal pembentukan BUMDes Keuneubah Indatu sudah beroperasi dengan baik dan juga mendapatkan respon positif serta dukungan dari aparatur desa dan masyarakat setempat. Pemerintah dan masyarakat desa ikut memberikan saran dan bimbingan untuk usaha BUMDes yang akan dibentuk. Namun pada tahun selanjutnya tambak yang menjadi program usaha BUMDes menjadi terbengkalai karena kurangnya serta lemahnya perhatian dari pemerintah desa dan masyarakat sehingga pengelola kesulitan dalam mengembangkan BUMDes agar tetap berjalan sesuai dengan tujuan yang dibentuk sebelumnya.

Dalam pengelolaan BUMDes Keunebah Indatu Gampong Lhok Euncien belum memiliki tim penggerak yang mampu menyelesaikan permasalahan baik dari segi permodalan maupun sistem pengelolaannya. Seharusnya setiap program perlu terus menerus diberi solusi bagaimana BUMDes ini ke depannya dapat berkembang dengan cara memberikan arahan serta bimbingan agar pengelola dan seluruh masyarakat dapat memahami maksud dari pembentukan BUMDes ini.

Dalam melakukan pengawasan dalam program pengelolaan BUMDes diharapkan seluruh pengelola maupun masyarakat juga ikut serta dalam mengawasi perkembangan BUMDes. Masyarakat jangan hanya mengharapkan aparat pengawas bertindak sendiri, tetapi juga hendaknya ikut melihat langsung bagaimana yang terjadi di lapangan, sama-sama mengawasi demi perkembangan program BUMDes.

219 | Jurnal Ilmu Sosial dan Ilmu Politik Malikussaleh (JSPM) Volume 1 Nomor 2 Tahun 2020 
Hasil temuan di lapangan menunjukkan bahwa, BUMDes Keuneubah Indatu Gampong Lhok Euncien tidak berjalan sesuai dengan fungsinya disebabkan karena lahan yang menjadi aset usaha BUMDes diserahkan pada pihak ketiga atau disewakan, sehingga pengelola BUMDes tidak bekerja secara efektif dan optimal. Adapun pengawas hanya mengawasi hasil dari laporan serta pendapatan tahunan saja, tidak diawasi menurut aturan yang semestinya dilakukan oleh seorang pengawas.

Dalam melakukan sebuah pengawasan, pengawas tidak cuma memiliki tanggung jawab kepada lembaga BUMDes melainkan juga kepada seluruh lapisan masyarakat, karena pengawasan tidak hanya berfokus pada pengawasan lapangan saja, namun juga pengawasan terhadap pengembangan usaha BUMDes serta permasalahan yang dialami dalam pengelolaan BUMDes itu sendiri. Jadi dibutuhkan komitmen yang kuat dalam pelaksanaan pengawasan.

Dalam setiap program pemberdayaan yang dibentuk oleh pemerintah desa tujuan utamanya adalah dalam rangka membantu menggerakan roda perekonomian masyarakat desa. Namun dalam pengelolaan program BUMDes Keuneubah Indatu terdapat beberapa hambatan yang dihadapi oleh pemerintah desa dan pengurus BUMDes yaitu berupa kendala keterbatasan modal serta minimnya sumber daya manusia (SDM) ditambah dengan kurangnya kepedulian masyarakat terhadap pengelolaan BUMDes.

Adapun hambatan yang menjadi puncak permasalahan dalam pengelolaan BUMDes yaitu minimnya penyertaan modal dikarenakan anggaran yang rencananya akan dialokasikan untuk pengembangan usaha BUMDes digunakan atau dianggarkan untuk pembangunan insfrastruktur terlebih dahulu, sehingga lahan tambak yang menjadi aset usaha BUMDes diserahkaan pada pihak ketiga untuk mengelolanya dalam jangka satu tahun. Minimnya penyertaan modal ini membuat BUMDes tidak bisa mengembangkan usahanya sesuai dengan target yang ditetapkan.

Selama ini pemerintah desa serta pengurus BUMDes belum tepat dalam mengatur dan mengelola anggaran dana desa karena masih menitikberatkan pada pembangunan yang bersifat nyata, tidak berfokus untuk mengembangkan program yang sebenarnya akan menjadi pendongkrak bagi perekonomian masyarakat desa, membuka lapangan pekerjaan bagi masyarakat, atau menambah wawasan dalam berwirausaha. Padahal apabila BUMDes bisa dikelola dengan efektif dan efisien yang sesuai dengan perencanaan yang telah disepakati bersama, kebermanfaatannya akan dirasakan secara langsung oleh masyarakat.

Namun permasalahan yang terjadi adalah sumber daya manusia (SDM) pengurus belum sesuai dengan yang dibutuhkan karena masih minimnya kompetensi dan pengetahuan yang dimiliki tentang bagaimana mengelola dan menjalankan BUMDes agar bisa berkembang. Desa kesulitan 
mencari sumber daya manusia (SDM) yang handal untuk mengelola BUMDes, dikarenakan keengganan dari masyarakat desa untuk mengelola BUMDes masih ada. Tingkat kesadaran masyarakat untuk mengelola BUMDes masih sangat rendah dikarenakan alasan sibuk mempunyai pekerjaan sendiri, sehingga tidak bisa sepenuhnya mengelola BUMDes dengan maksimal.

Kurangnya partispasi masyarakat terhadap pengelolaan BUMDes karena masyarakat masih apatis, banyak yang tidak peduli terhadap program yang dikeluarkan ataupun dibuat oleh pemerintah. Walapun program BUMDes ini dibentuk berdasarkan musyawarah ataupun kesepakatan dari seluruh masyarakat, dalam implementasinya tetap saja tingkat kepedulian masyarakat terhadap BUMDes ini masih sangat rendah. Sebenarnya partisipasi dari masyarakat sangat diperlukan dalam pengelolaan BUMDes karena ini menjadi motivasi untuk BUMDes menjadi berkembang. Apabila mendapat dukungan dari semua pihak, mengelola BUMDes menjadi terasa mudah.

\section{KESIMPULAN}

Berdasarkan hasil penelitian yang dilakukan oleh peneliti mengenai Sistem Pengelolaan Badan Usaha Milik Desa (BUMDes) dalam Pembangunan Tambak Milik Desa pada BUMDes Keuneubah Indatu Gampong Lhok Euncien Kecamatan Baktiya Barat Kabupaten Aceh Utara, maka diperoleh kesimpulan sebagai berikut :

Badan Usaha Milik Desa (BUMDes) Keuneubah Indatu desa Lhok Euncien didirikan pada tahun 2017 berdasarkan hasil musyawarah desa dengan tujuan meningkatkan kesejahteraan masyarakat desa, membuka lapangan kerja baru, serta untuk mendapatkan pendapatan asli desa agar desa mandiri dan berkembang.

Pada tahap perencanaan sudah membeli lahan tambak sebagai aset usaha BUMDes namun dikarenakan minimnya modal sehingga lahan tersebut disewakan, pada tahap pengorganisasian dan penggerakan masih kurangnya keterlibatan serta tanggung jawab dari pemerintah desa dan pengurus BUMDes dalam mengembangkan usahanya, serta pada tahap pengawasan kurangnya keikutsertaan dari semua pihak baik dari pemerintah desa, pengurus BUMDes dan masyarakat dalam mengawasi program BUMDes yang didirikan.

Hambatan yang dihadapi dalam program BUMDes Keuneubah Indatu Gampong Lhok Euncien yaitu terkait dengan keterbatasan modal dikarenakan dana desa yang rencananya akan dialokasikan untuk pengembangan usaha BUMDes dialihfungsikan terlebih dahulu untuk pembangunan insfrastruktur. Ditambah dengan minimnya sumber daya manusia (SDM) dan kepedulian masyarakat dalam pengelolaan usaha BUMDes sehingga sulit berkembang.

221 | Jurnal Ilmu Sosial dan Ilmu Politik Malikussaleh (JSPM) Volume 1 Nomor 2 Tahun 2020 
Diharapkan kepada pemerintah desa, pengurus BUMDes serta masyarakat Gampong Lhok Euncien lebih meningkatkan kepedulian serta tanggung jawab bersama dalam kegiatan monitoring serta evaluasi dalam pengelolaan BUMDes, agar dapat mengatasi dan mencari solusi terkait dengan permasalahan dalam sistem pengelolaannya, sehingga BUMDes Keuneubah Indatu dapat berjalan dengan baik sesuai dengan semangat pembentukannya, dan dapat memberikan mamfaat bagi masyarakat dan bagi Gampong Lhok Euncien.

Perlu juga diadakan pelatihan serta sosialisasi bagaimana sistem pengelolaan BUMDes kepada pengurus agar meningkatkan kinerja sehingga usaha BUMDes menjadi berkembang. Sosialisasi terhadap masyarakat juga diperlukan agar mereka mengetahui pentingnya partisipasi dalam program BUMDes untuk meningkatkan pendapatan dan perekonomian bagi desa.

\section{DAFTAR PUSTAKA}

Abu, R. (2019). Peran Badan Usaha Milik Desa dalam Pemberdayaan Masyarakat (Studi di Desa Labaraga Kecamatan Wakorumba Utara Kabupaten Buton Utara). Disertasi. Universitas Halu Oleo.

Adisasmita, R. (2006). Pembangunan Pedesaan dan Perkotaan. Graha Ilmu.

Arif, M. (2007). Tata Cara Pengelolaan Desa dan Pengelolaan Keuangan Desa. Red Post Press.

Ahmadi, A, \& Uhbiyati, N. (2001). Ilmu Pendidikan. Rineka Cipta.

Budiman, A. (1995). Teori Pembangunan Dunia Ketiga. PT Gramedia Pustaka Utama.

Damanhuri, D. S. (2010). Ekonomi Politik dan Pembangunan: Teori, Kritik dan Solusi bagi Indonesia dan Negara Sedang Berkembang. PT Penerbit IPB Press.

Herdiansyah, H. (2010). Metodologi Penelitian Kuantitatif. Salemba Humanika.

Iskandar (2009). Metodologi Penelitian Kualitatif. Agung Persada Pers.

Kansil, C. S. T. (1983). Desa Kita dalam Peraturan Tata Pembangunan Desa. Ghalia Nasional.

Manikam, A. S. (2010). Implementasi Program Badan Usaha Milik Desa di Desa Ngeposari Kecamatan Semanu Kabupaten Gunung Kidul Tahun 2009. Skripsi. Jurusan Ilmu Pemerintahan FISIP UMY.

Narbuko, C., \& Achmadi, A. (2007). Metodologi Penelitian. Bumi Aksara.

Peraturan Menteri Dalam Negeri Nomor 39 Tahun 2010 tentang Badan Usaha Milik Desa.

Peraturan Menteri Desa, Pembangunan Daerah Tertinggal, dan Transmigrasi Nomor 4 Tahun 2015 tentang Pendirian, Pengurusan, Pengelolaan, dan Pembubaran BUMDes. 
Harun, R., \& Ardianto, E. (2011). Komunikasi Pembangunan \& Perubahan Sosial: Perspektif Dominan, Kaji Ulang, dan Teori Kritis. Rajawali Pers.

Subandi (2011). Ekonomi Pembangunan. Alfabeta.

Sugiyono (2017). Metode Penelitian Kuantitatif Kualitatif dan R\&D. Alfabeta.

Suparno, A. \& Suhaenah. (2001). Membangun Kompetensi Belajar. Direktorat Jendral Pendidikan Tinggi Departemen Pendidikan Nasional.

Terry, G. R. (2009). Prinsip-Prinsip Manajemen. Bumi Aksara.

Todaro, M. P. (2000). Pembangunan Ekonomi di Dunia Ketiga. Erlangga.

Undang-Undang Nomor 6 Tahun 2014 tentang Pemerintahan Desa

Undang-Undang Nomor 23 Tahun 2014 tentang Pemerintahan Daerah.

Widjaja, H. A. W. (2005). Otonomi Desa Merupakan Otonomi yang Asli Bulat dan Utuh. PT RajaGrafindo Persada. 